\title{
CULTURAL-HISTORICAL PSYCHOLOGY OF L.S. VYGOTSKY: EXPLORING THE LOGIC OF MULTIDIMENSIONALITY
}

\begin{abstract}
Vitaly E. Klochko
Tomsk State University

Tomsk

Cultural-historical theory of L.S. Vygotsky is viewed in the paper through the prism of tendencies of psychology development, which are revealed by the transspective analysis understood as a tool of cognition of regularities of emergence of open self-developing systems to which science can be attributed. It is argued that cultural-historical psychology can be placed among the theories of post nonclassical level; i.e. having declared itself at the age of emergence of non-classical psychology, the theory left its time behind. This fact significantly hindered (and is still hindering) comprehension of the multidimensional logic applied by L.S. Vygotsky. It is shown that today this logic is becoming much more accessible for comprehension as science has started to embrace the ideals of post non-classical rationality. System anthropological psychology is considered as a modern version of cultural-historical psychology development, which has retained the original multidimensional logic applied by L.S. Vygotsky.
\end{abstract}

Keywords: cultural-historical psychology; multidimensional logic; philosophy of multidimensionality; psychology of multidimensionality, system anthropological psychology.

As the Second International Congress, which was organized by the International Society for Cultural and Activity Research (ISCAR) and took place in September 2008 in San Diego (UCSD), has vividly demonstrated, over the period of the existence of L.S. Vygotsky's theory some of its interpretations have changed and, besides, there have emerged some tendencies caused by the processes of hyperglobalization in modern research based on L.S. Vygotsky's theory. M. Cole delivered a lecture sharing his vision and hypothesis on further development of L.S. Vygotsky's

The research was conducted within the framework of the Federal Special Program "Scientific and Scientific-Pedagogical Professional Community" for the period of 2009-2013. 
theory in the future. In this paper I would like to make an emphasis on some of other issues.

Psychology has been developing over the last 75 years in such a way that a new interpretation of L.S. Vygotsky's work comes in as a sign of the science progress. That is why prognoses may be brought into another sphere. What is the real direction that development of modern psychology takes? May it be so, that objective tendencies of its development are the ones that provided an opportunity to comprehend and assimilate the methodological potential that had been embedded in the theory? In other words, it is possible that L.S. Vygotsky who deeply felt the tendencies of science development managed to figure out the general vector of such development and endeavoured to elaborate a theory which would pass ahead of its time. Therefore, S. Toulmin called him "The Mozart of Psychology," i.e. the scientist whose style of thinking, though not always transparent, makes an impression of "the state of the art methodological culture"; and we have a long way to go before we can attain this level of culture. (Toulmin, 1981). It is not by chance, that L.S. Vygotsky would call his theory "top psychology."

I maintain a standpoint, which I have repeatedly expressed, that L.S. Vygotsky is "a classic of post-nonclassical psychology" that is the reason why he had not been understood by his contemporaries who at that point were mastering the basics of non-classical thinking and why he remains enigmatic for our time, when methodology of post-nonclassical science has only begun to establish itself (Klochko, 2005; 2007; 2008; Klochko \& Galazhinsky, 2009). My position got strengthened after the analysis of scientific diaries and notes of L.S. Vygotsky published in 2008 (Zavershneva, 2008), in which he contemplates over the causes of the crisis that stroke the theory in 1930-1934; i.e. during the last four years of the scientist's life; those directions of thinking which he considered to be the wrong, as well as some other ideas about possible ways to remedy the situation which he did not manage to develop and apply. In this paper I will make an attempt to demonstrate that despite the fact that this self-critical analysis had not been available to us at the beginning of 1970s, the power of ideas embedded in the axiomatics of the theory, as well as guesses about the tendencies of science development, made it possible for the followers of this theory to approach the solution to those problems which were singled out by L.S. Vygotsky, and what is more, in the way that he had intended. 
By the "followers" of cultural-historical psychology in this case I mean A.N. Leontiev, his student O.K. Tikhomirov who created the semantic theory of thinking, and later held a chair of the department established by A.N. Leontiev; I mean us, the students of O.K. Tikhomirov, myself in particular, and at the present moment my students as well. That is why ideas that will be discussed in the paper should not be considered as a claim to develop "the one and only correct" conception of culturalhistorical psychology, which goes back to its founder, but one of many diverse ways of its development, which nevertheless follows an active style of thinking and experimentation and a particular view on evolution of historically established self-developing "human dimensional" systems (the transspective analysis).

\section{L.S. Vygotsky: mastering multidimensionality}

What distinguished L.S. Vygotsky from his contemporaries and what still marks him out among modern methodologists is the particular level of systems thinking. This is what makes us perceive him as "The Mozart of Psychology" as the thinking of the adequate level is necessary for deciphering Vygotsky's ideas. I am not claiming that I have mastered this style of thinking: during 75 years that past after L.S. Vygotsky, the science has gone a long way that brought it closer to understanding of the fundamental ideas of cultural-historical psychology and, consequently, to their acceptance. For a comparatively long period of time the supporters of this theory in Russian science did not show any special activity even in response to direct and indirect challenges. It did not happen because they worked insufficiently or had nothing to say to support the theory. In one of my books I expressed my vision of the drama which was experienced not only by L.S. Vygotsky, but as well by O.K. Tikhomirov, and those who were in the scientific school of O.K. Tikhomirov and came up with experimental studies of dynamics of sense-making as a basal foundation of selectivity of consciousness and thinking (Klochko, 2005). Everyone of us, though in a different way, would face the problem of M.M. Bakhtin: "what I want to say, and what I can say to be understood." Through experimental verification of L.S. Vygotsky's hypothesis about the unity of the intellect and affect we received data which could have been represented, but its interpretation required evidence from the field of neurophysiology of emotions that did not exist at that time. I made an 
observation in my book that the closer science approaches the research of human worlds, the establishment of multidimensionality of life spaces and value-sense evolvement of people's real being, the clearer becomes the methodological significance of the ideas which were developed by O.K. Tikhomirov and his students. But initially that multidimensionality was explored by L.S. Vygotsky.

I believe that psychologists are going to accept the idea of L.S. Vygotsky - that the "positive role" of psychic is not to reflect the world, but to "subjectively distort reality for the benefit of an organism" (Vygotsky, 1982 , p. 347) - as the axiomatic basis of cultural-historical theory. For only through such "distortion" a person gets the opportunity to act consciously, i.e. to comprehend the sense and value of their actions. I insist that this idea in particular forms the basis of systemic studies of L.S. Vygotsky: psyche and consciousness are not identical with reflection of the world. Their functional meaning lies in the generation of a multidimensional reality that cannot be reduced to either a subjective reality, or an objective one. Pretersensual dimensions of objects constituting "the external field" of a person's being inalienable from a person and included into the definition of a person as an integral phenomenon are formed in this generative interaction of a person with the world. "Is commodity $=$ pretersensual thing $($ Marx) possible without psyche? The essence of psyche from a positive side... is an intentional attitude towards an object" (Vygotsky, 1986, p. 59).

But one would have to come up to these pretersensual (psychological) features of objects through an incredibly complicated move, i.e. introduction of attitude into reflection, matching "two sides of an indivisible characteristic of consciousness. One side is processual, another side is phenomenological and sense-based, being at the same time objective" (Leontiev, 1994, p. 36). Continuous search for "psychological features of the external" (Vygotsky, 1982, p. 106) through which a person acquires an ability to influence themselves, their psyche and behaviour, signified the whole epoch in the establishment of cultural-historical theory. "One is required to find in this external object what makes it psychological in particular. The answer to this question was the theory about the role of an object as a unit of consciousness. The result was, however, quite unexpected..." (Leontiev, 1994, p. 39). The idea of "psychological tools (instruments)" mediating relations of a person with the world has always been readily accepted by psychologists, and sometimes almost the en- 
tire conception of L.S. Vygotsky can be discovered in this "instrumental mediation." Yet, the idea was more profound. L.S. Vygotsky was striving to resolve the problem of connection between life and consciousness, which was represented for him in the unity of affect and intellect. Later A.N. Leontiev wrote about this problem that it had never been resolved "in the sense of a backward move: affect - intellect. It could not have been resolved" (Leontiev, 1994, p. 39).

Today through the analysis of diary notes of L.S. Vygotsky we get to know that he finally figured out what he called "a mistake of our analysis"; in particular, he came to realize that the mistake was in the separate analysis of the external field and the field of sense. He understood that such "parallelism" breaks down their unity: "one has to take an indivisible aspect" and come out to "the flowing dynamics" of life, to "dynamics of the flussig kind" (Zavershneva, 2008, p. 132). How is one to take "the indivisible aspect" of the field of sense and the external field? How do these fields co-exist in reality? As a matter of fact, this is the exploring of a person's life space multidimensionality that can be discovered through special types of systems analysis. At this point L.S. Vygotsky figured out another mistake: the crisis of the theory was not in the lack of data, but in "the failure" of the theory as it was; "we were too late to introduce the systems point of view. Now I've got a deeper understanding of that" (Zavershneva, 2008, p. 132). It is strange to hear that from a person who dedicated his life to persistent development of the theory of "psychological systems" (superior psychological functions). But the focus of the discussion was that such systemacy was required which could save the theory. A.N. Leontiev commented on the situation in the following way: "what has been disconnected at the initial stage cannot be connected at the final stages. Consequently, it is necessary to find some connection in the disconnected" (Leontiev, 1994, p. 39).

Now let us evaluate the breakthrough of a theory, which was trying to grasp the logic of multidimensionality adequate to post-nonclassical paradigm of the end of 1920s, i.e. at the time of the golden age of classical paradigm preferring one-dimensional logic and emergence of non-classical paradigm, which was yet based on the binary logic contrasting an objective reality with a subjective one, the inner world of a person with the external world, consciousness with unconscious, psychic with physical etc.

In fact, it was a statement against anthropology of M. Sheller in which the fields of sense are from the very beginning isolated from the 
fields of objects. Vast body of theories and practices of humanistic and existential orientation, including those of the followers of V. Frankl, is still based on this idea of initially determined sense which can be discovered, but cannot be constructed. Apart from this, it was the exploration of the logic of multidimensionality, which was supported neither by philosophy which only now comes to elaborate philosophy of multidimensionality, nor by the general systems theory, which moved on to self-developing systems a lot later. However, development was already considered from an ontological perspective in cultural-historical psychology - "the process of development is represented in changes of the field of sense" and, accordingly, in the changes of the external field which is inseparable from the field of sense. Let us discuss this issue in more detail.

\section{Philosophy of multidimensionality}

Why does it happen that cultural-historical psychology still has to force its way in science? It happens because the logic of multidimensionality is just becoming the tool of professional thinking in psychology and philosophy. If we try to briefly characterize the state of modern psychology, the following description suggested by Yu.M. Lotman may well be referred to our science: "the process that we all witness can be described as a transition from a binary system to a ternary one. One cannot but mention the peculiarity of the moment: the transition itself is thought of in traditional concepts of binarism" (Lotman, 2000, p. 146). What is going on today in our science can be regarded as a "painful farewell" to habitual understanding of the psychic within the framework of dual constructions and binary models.

It is indeed "a painful farewell," as all endeavors to overcome the dichotomy, when it is being diagnosed as something that hinders the progressive development of science irrespective of the fact where this dichotomy is revealed (external - internal, subjective - objective, psychic physical, affect - intellect, consciousness - unconscious, etc.) are blocked by "rigid deterministic" style of thinking (V.V. Nalimov) through which this dichotomy is being overcome. This style itself sprang from the heart of the binary logic, was nourished on the opposition of polar points and still exists on the opposition which constitutes the privilege of this style of thinking. Even when this style mimicries into the externally dialectic 
form "both the one and the other," behind it can still be hidden what is the most important - "the third is not given."

That is why quite often any effort to introduce the third is being unconsciously blocked. For example, an effort to introduce the third in between objective and subjective realities is being blocked, i.e. to introduce "a life space" (K. Lewin) which cannot be reduced to binary oppositions; or "the field of sense," "transitional (from Spirit to matter) form" (L.S. Vygotsky), or "the transsubjective" (D.N. Uznadze), or directly "the multidimensional world" (A.N. Leontiev), not talking about "the psychological features of the external" (L.S. Vygotsky, A.N. Leontiev) in which apart from all the rest "spiritualization of the matter" is still being present. Representatives of the binary logic demand explanations: "where exactly is the observer located?" Possible answers, even the most correct ones, are not likely to satisfy them, and this is natural, as they want to get an answer which would fit their logic, the answer which would not change their position and would not force them to move on to a thinking style based on a different logic.

Of course, it is interesting to observe the discourse, when nothing less than the problem of freedom (in its binary connection "freedom determinism") is being discussed in such a rigid deterministic style. Variations on the topic "either freedom, or determinism" quite often look like a controversy which leads to nothing but denial of the right to exist for one of these categories. Reasoning of the kind "both the one and the other" leads to profound maxims like "freedom is determined by not being determined by anything at all."

As some philosophers believe, the transition to multidimensionality "implies a revolution in categorical framework of scientific and philosophical knowledge, a search for other logical and methodological underpinnings" (Dryuk, 2002, p. 30). Switching form a binary system to a multidimensional one is the process of choosing a new way of looking at the world, but an immediate transition of a researcher (or a scientific school or science itself) to a new style of thinking is impossible. Transitional period is necessary for the science to be able to elaborate categories adequate to a new logic which do not yet exist or are at the stage of emergence. The lack of established scientific concepts makes psychologists resort to metaphors. This proves that T. Kuhn was right when he argued that in transitional (to a new paradigm) period "science begins to speak the language of metaphors." 
A philosophical problem, according to V. Altukhov, is that worldwide philosophical, social and political thought cannot find any other logical grounds except for the principles of an outdated monism, which has long ago become a conceptual basis of totalitarianism and classical pluralism, bringing with it into the theory and political practice its original, primary meaning (diversity devoid of the inner (substantial) unity) and generating new forms of world outlook and political confrontation" (Altukhov, 1992, p. 18).

The most difficult, from my point of view, is that exploring the logic of multidimensionality implies going beyond the limits of an established discrete understanding of the psychic (consciousness) as no one knows where localized, but systematically, structurally and functionally shaped phenomena ("spheres"), which are constantly functioning, continuously doing something (psychic activity, activity of consciousness) to a person, instead of a person, or together with a person. Today, some limit becomes obvious when an increasing number of psychologists come to understand that functions of psyche and consciousness cannot be revealed in the process of their studying, i.e. without entry into the system in relation to which they perform that function. None of the methodological tricks (such as the definition of psyche as an integral system (let it even be open, self-regulating, self-organizing etc.), or definition of consciousness as a self-acting organ which has its own logic, following which it makes a decision what is worth realization and what is not) will help to work it out. For the first time psychology calls for bringing back "an integral person," i.e. a person comprehended in a special way and regarded in the unity with all multidimensionality of a person's being within multidimensional life space, constructed on their own; though an appeal to "bring back an integral person into psychology" was made public a long while ago (Leontiev, 1975, p. 304). The notion of consciousness becomes relevant not to particular sub-systems (activity, behaviour, personality, subject etc.), but to a person who is realizing their own life. We are to accept the rightfulness of L.S. Vygotsky: it is "life that determines life through consciousness" (Zavershneva, 2008, p. 129), and we still persist in defining consciousness outside the context of life, being surprised by the fact that it (consciousness) would not reveal itself to us either in its functions, or in its nature.

The problem of consciousness cannot be resolved following the logic of binary oppositions: the time for putting forward problems of such 
level is only coming. This conclusion is justified by current relevance of such categories as meaning, sense, value. If categories which come from "the multidimensional future" are being applied in "the binary present," then it might represent the transition of a system to the multidimensional logic. Sense is the plenipotentiary of the future in the present, of the multidimensional in the binary. The "drama" of the category "sense" is that a binary construction cannot be sustainable without appealing to this notion as it is necessary for explanation of discrepancies generated by the imperfections of applied thinking, but the meaning of the category "sense" is not disclosed because it cannot be disclosed in the system of alien to it (to "sense") categories. Furthermore, it was precisely pointed out by V.V. Nalimov that: "if the senses are not being made sense of, then they begin to fade away" (Nalimov, 1993).

In other words, the above-mentioned drama of the "sense" category unfolds as the category is "fading away" in the process of transition, remaining a forerunner of a revolutionary renewal of a conceptual system of science. If such revolution happens, and it will happen when separate researchers will close their ranks consciously mastering a new paradigmal space, then the correctness of A.N. Leontiev's prediction that the notion of sense really "can lay claims to a new, higher methodological status, to a role of a key notion in a new non-classical or post-modernist psychology" (Leontiev, 2003, p. 4) will be justified.

A certain generalization of philosophical problems of multidimensionality can be done drawing from V.E. Kemerov's studies. The nature of problems that he investigates brings him close to the scholars most interested in psychology of multidimensionality. Discussing the problem of multidimensionality of the social being within the framework of social philosophy, V.E. Kemerov marks out those difficulties that come up while exploring the logic of multidimensionality (Kemerov, 2002). This is the problem of a long-range action that has not yet been adequately evaluated and interpreted. It is closely connected with another problem: the ability of science to single out pretersensual objects and to work with them. V.E. Kemerov argues that philosophy, having focused on criticizing the stereotypes of classical scientific character and rationality, has done hardly anything to develop new scientific and philosophical means of fixation and description of pretersensual aspects of being. The author maintains that one-dimensional notion of a human activity cannot be a sufficient characteristic of pretersensual aspects of being of objects and 
especially of people. When "human objects" get into a lively motion of activity they disclose their multidimensionality by getting involved in a life process of a developing personality of a child or an adult. Process, organization, advancement in time and space of human active powers are hiding behind the term "pretersensual." What makes it even more complicated is the consequence of the multidimensional logic, that is acknowledgement of the fact that the conscious and the spiritual are the expressions of pretersensual complexity of human existence understood in its continuality. Different stages of the social process would give priority to various aspects of spatial-temporal exploration and representation of the world by a person. Today, the process of "resetting the coordinates" is going on: if previously spatial forms expressed time and subdued its measurement, then time becomes the dominant in modern understanding. The turn of present day science towards qualitative analysis of complex systems has connected space and time with their organization. V.E. Kemerov argues that the ancient idea of chronotop becomes again the reference point of world outlook, but the idea of chronotop will remain just a reference point without specific research of space-time as forms of being of complex cultural and natural systems.

It is interesting that L.S. Vygotsky anticipated many issues that are singled out in modern philosophy of multidimensionality. Long before our time he had suggested the connection between psyche and pretersensual features of objects and phenomena. He was the first to understand the necessity of reconciliation of the field of sense and the field of objects, thus having closely approached the understanding of the life space of a person in its multidimensionality. Behind the concept of psyche as "subjective distortion of objective reality" there appears the idea of a long-range action, the idea of continuality of psyche, its continuity in space and time. L.S. Vygotsky did not simply distinguish a dominating character of time, he insisted on the necessity of interpretation of psychological phenomena "not only from the past, but from the future as well," asserting that a new theory which he was developing "introduces an extremely valuable for a psychologist perspective of the future," that "in this new theory a revolutionary perspective of the future allows to understand development and life of a personality as an indivisible process heading forward" (Vygotsky, 1993, p. 153-165). Scientific intuition allowed the scientist to formulate solutions which were not always based on a conclusion, and scientific integrity allowed him to admit the following: "I do not have enough theo- 
retical power to combine all this" (Vygotsky, 1992, p. 131). An amazing flair for new tendencies in psychology and ability to keep his "new theory" within the course of these tendencies - this is the genuine Vygotsky. This is expressed by the last note he made in his life: "This happens to be the last of what I have accomplished in psychology, - and I will die on the top like Moses, having cast a glance over the Promised Land, but have never had a chance to step on it" (Zavershneva, 2008, p. 135).

Vygotsky was right when he wrote about the system of objective tendencies of science development "acting behind the backs of individual researchers and theorists with a force of a steel spring" (Vygotsky, 1992, p. 124). I was the one to experience the force of these "steel springs." To do that I had to approach the problem of "unity of affect and intellect" put forward by L.S. Vygotsky. But who would have thought that it would be enough to trigger the mechanisms carrying a researcher away into the logic of multidimensionality.

\section{Psychology of multidimensionality: system anthropological psychology}

My own exploration of the logic of multidimensionality was initiated by a discovery made in the scientific school of O.K. Tikhomirov (who is known now as the founder of the semantic theory of thinking). It was the discovery of the phenomenon of emotional anticipation in the regulation of an intellectual activity. The anticipating function of emotions was fixed in relation to the process of cognitive goal-forming, motiveforming in studies by O.K. Tikhomirov, Yu.E. Vinogradov, I.A. Vasiliev, V.A. Terekhov. The only thing left unanswered was the following: it was characteristic of cognitive psychology of that time to explain cognitive procedures without engagement of emotional factors, though facts were discovered in the laboratory of O.K. Tikhomirov which proved that emotional evaluations precede logical ones, that logical procedures are carried out by a subject in those sectors of an objective situation which are marked with "emotional colouring" etc. It had been 15 years prior to the discussion of a thesis about the primacy of affect in comparison with cognition, which was brought up by Rober Zajonc (Zajonc, 1984); the discussion did not yield any results and gradually faded away. It seems quite natural, since in the binary logic of cognition, which methodological basis was gnoseology of reflection, this problem is not being re- 
solved. It might be approached on the methodological basis of ontology of reflection, in which interaction of the objective and the subjective was viewed through the generation of "reconciled" (systemic, pretersensual) features in this interaction, but elaboration of such ontology remains the task for the future. Philosophy of multidimensionality is one of the ways to accomplish this task.

A certain clarity was established after the experimental discovery of value-sense dimensions of the situation of activity (in the middle of 1970s). At that point the immediate purpose was to understand the mechanism of generation of values and senses as special (pretersensual, systemic) features of objects and phenomena, constituting conditions of activity. Value-sense structure of a situation turned out to be in particular the dynamic factor which reconstructs itself under the influence of internal changes (ever changing cognitive needs, motives and goals). But it was difficult to figure out how the external (situation) reacts to these internal changes through dynamics of "informal, value-sense structure of a situation" (the term of O.K. Tikhomirov).

"If the problem has not been resolved over the centuries, then it is necessary to alter the way of thinking with the help of which we work on it," - writes A.G. Asmolov in his commentary to the text of D.N. Uznadze (Uznadze, 2000, p. 110). Nevertheless, being unaware of that, we have corrected "the mistake" of L.S. Vygotsky, by uniting the field of sense with the external field, fixing in the process of an experimental research the dynamic of value-sense dimensions of objective conditions under which the activity occurs. We could not possibly suspect that what was going on should imply far-reaching and profound consequences, i.e. that we were about to step beyond the limits of a discrete understanding of psyche and consciousness towards the recognition of their continuality. But a lot more time will be required for psychology to master the logic of multidimensionality without which it would be impossible to assimilate the logic of continuality in which the psychic represents itself in its temporal and spatial continuity (Klochko, 2005; 2007; Klochko \& Galazhinsky, 2009). On the other hand, along with concepts of "the psychological field" (K. Lewin), "the field of sense" (L.S. Vygotsky), "the transsubjective space" (D.N. Uznadze) the idea of spatial continuity of the psychic has been maturing for quite a long time. The psychic is the thing that ensures the long-range action of a person as an open self-developing system at the same time defining the parameters of a person's multidimensionality. 
Even though a lot of people have agreed upon the idea of self-organization in spatially-distributed systems that potentially possess an infinite number of degrees of freedom through allocation of a small number of the so-called "parameters of order" (variables which determine dynamics of the whole system). But it is still quite difficult to embrace the idea that senses and values are indeed those parameters of order (attractors) based upon which a person exercises the choices of life directions in which selfrealization and self-development become possible. That is the reason why it is so difficult to accept the coincidence principle of D.N. Uznadze, who having sequentially analysed alternating theories of empirism, nativism, convergence, each in its peculiar way establishing interrelations between the external and the internal in behaviour and development of a person, arrived at a conclusion that "the concept of the internal already has in its contents what is considered to be the external, and vice versa, - the concept of the external already has what is considered as the internal" (Uznadze, 2000, p. 110). He proceeds with maintaining that the idea of "demarcation" and independence of the internal and the external in relation to each other, that is the axiomatic foundation of all those theories, "absolutely does not comply with the real situation: this is a complete misconception which cannot be productive as a premise for theoretical reasoning" (Uznadze, 2000, p. 110 ).

Emotions make senses "visible," or to be more precise "viable," for a person. Emotions are that specific device for reflection of these pretersensual features and at the same time a form in which they exist for a person. What has a meaning, makes sense and has a value for a person, acquires a chance to get into consciousness. The rest blurs against the background, but if the eye could see everything, then it would see nothing" (Vygotsky, 1982, p. 347).

System anthropological psychology originated on the basis of the theory of psychological systems (known under the abbreviation TPS) that has been actively elaborated over the last 25 years. The basis of this theory is built upon coherent realization of the idea of unity of a person with their multidimensional world as inseparable from a person themselves and as a representation of the human nature. The person is considered in the dynamics of self-accomplishment, in their openness to the world as well as towards themselves. The relationship between complexity growth of a person's multidimensional space of life in ontogenesis on the one hand, and emergence of adequate (to these changes) forms 
of consciousness - objective, notional, value, on the other, - was established on the basis of vast body of research. In the process of study of autocommunication we managed to approach the solution to the problem of intelligence of consciousness, which L.S. Vygotsky regarded as the most challenging among all the problems which psychologists-researches have ever addressed (Vygotsky, 1982). New directions of development of multidimensional logic leading to studies of a person as a special spatialtemporal unit that is an open towards the world, self-developing system with inherent temporal manifestations and systemic determination of innovative forms of life accomplishment are explored in doctoral theses of O.M. Krasnoryadtseva (1997), E.V. Galazhinsky (2002), A.K. Belousova (2003), E.V. Nekrasova (2005), T.G. Bokhan (2008), O.V. Lukyanov (2009).

What can cultural-historical psychology offer in any of its variations if it has not yet lost its original link with the methodology suggested by L.S. Vygotsky? There is one particular task, for solution of which mathematicians and synergists turn to psychologists. "In contrast to synergists, hints ironically G.G. Malinetsky, - our brain finds no difficulty with selection of parameters of order and building effective predictive systems (predictors). Indeed, "CPU clock rate" (where CPU stands for central processing unit) and a signal transmission rate of the brain are 6 times lower as compared with a personal computer. "That is why we have to ruthlessly edit the incoming information flows and process only the most important," but how does it really happen? (Malinetsky).

How important is it to accomplish this "technical task"? "Since it fails to work out good predictive computer systems "on common grounds" in all multidimensional phase space, - G.G. Malinetsky observes, - our brain seems to take into account its heterogeneity. Apparently, it identifies with amazing accuracy the areas where the multidimensional space can be substituted for a one-dimensional, and the complex can be substituted for the simple..." (Malinetsky). If psychology comes to answer the question of how it actually happens, then this knowledge might turn out to be quite significant both for synergists and for developers of "predictive" computer systems.

"In his time, E. Vigner, discussing the limits of science, distinguished two "metadisciplines" which offered universal and self-coordinated picture of the world. These were physics and psychology. From the point of view of a dilettante as the author of these notes considers himself, - 
G.G. Malinetsky writes with self-criticism, - psychology, as its development had shown over the last 20 years, did not meet the challenge" (Malinetsky). Here I should disagree with a well-known mathematician, one of the leading experts in the field of non-linear dynamics.

We can hardly blame mathematicians for the fact that they fail to make it out how L.S. Vygotsky's idea is being disclosed in the transspective of historical development of the science. It is the idea that psyche is exactly what allows a person to shape a multidimensional space around them, due to which neither brain, nor consciousness has to process the whole incoming information flow: "our feelings give us the world in excerpts, extracts which are important to us," as a result of that "consciousness follows the nature in jumps making gaps and blanks" (Vygotsky, 1982 , p. 347). We can hardly blame mathematicians for that because the majority of psychologists missed that elegant solution to the problem of selectivity of a human consciousness and behaviour which is embedded in this idea, even though not yet in an explicit form.

It turns out that neither brain, nor consciousness would determine the selectivity of psychic reflection. They receive the already selected data and the brain which "CPU clock rate" and a signal transmission rate are indeed "6 times lower than those of a personal computer" copes with the task of processing incoming information. That is why a nice metaphor about the brain which has to "ruthlessly edit incoming from the outside information flows" to deal only with "the most important" remains just a metaphor. "The ruthless editor" has already done his job and the brain receives previously selected and particularly structured information. In a pretersensual world everything significant gets marked with senses as attitude has already highlighted important points with its emotional "highlighter." Why is it that such an emphasis is put in synergy on brain which in an unknown way "edits" information flows? For the same reason as in psychology this role is attributed to consciousness. It sometimes gets assigned with the role of an autonomous figure which edits information flows, independently making decisions whether something is worth realizing or not. It remains unclear for whose benefit this "figure" makes these decisions. Is it for the benefit of a person? But this genuine figure responsible for the selection of information that is worth realizing does not exist in the theory of consciousness built on the idea of a direct connection of consciousness with information flows. This is the reason why the goal of a number of interesting, large-scale studies is formulated 
as "to prove the existence in the functional organization of consciousness of a decision-making mechanism to realize" (Agafonov, 2006, p. 3).

It happens because mathematicians as well as many psychologists apply one scheme - the simplest, and the most obvious scheme of world cognition (perception) by a person. A noted methodologist K. Popper referred to it as "the bucket theory." According to this theory, sensual data "is poured into a bucket through seven well-known openings - two eyes, two years, a nose with two nostrils and a mouth, and also through skin - an organ of touch. In a bucket sensual data is digested, and to be more precise, is assimilated, associated and classified. And then we receive our scientific theories from the recurring data through review, association, generalization and induction. The bucket theory or observationism is a standard theory of cognition from Aristotle to some of my contemporaries, for example. Bertrand Russell, a great evolutionist J.B.S. Haldane or R. Carnap. This theory would be shared by the first one who comes along," - wrote K. Popper (Popper, 1984). In principle, it is already not that important what lies in the centre of "the bucket": brain or consciousness. What is important is that such approach does not allow to resolve the problem of the selective behaviour of a person, and, above all, - innovative behaviour. A person is not "a bucket" in the centre of which there is brain or consciousness which processes information without bias.

The conception of psyche as of a device of reflection of the external world with its direct influence on the organs of senses which is embedded in "the bucket theory" by default does not allow psychology to solve the problems it encounters today. Psychology forces its way ahead to "an integral person," to multidimensional human worlds constituting "the most human" part of what the notion of "a person" is comprised of. Only exploration of these worlds can guarantee the solution to the discussed above problem of selectivity.

\section{References}

Agafonov, A.Yu. (2006). Fenomen osoznaniâ v kognitivnoj deâtel'nosti [The Phenomenon of Consciousness in Cognitive Activity] (Abstract of Doctor of Sciences dissertation). Saint Petersburg.

Altukhov, V. (1992). Filosofiâ mnogomernogo mira [Philosophy of Multidimensional World]. Obŝsestvennye nauki i sovremennost', 1 . 
Dryuk, M.A. (2002). Sovremennye koncepcii mnogomernosti kak novoj paradigmy myšleniâ [Modern Conceptions of Multidimensionality as a New Paradigm of Thinking]. Vestnik Moskovskogo universiteta. Seriâ 7 "Filosofiâ," 2.

Kemerov, V.E. (2002). Social'naâ filosofiâ [Social Philosophy. Lectures]. Yekaterinburg.

Klochko, V.E. (2005). Samoorganizaciâ v psihologičeskih sistemah: problemy stanovleniâ mental'nogo prostranstva ličnosti [Self-organization in Psychological Systems: Problems of Mental Sphere of a Personality Emergence]. Tomsk.

Klochko, V.E. (2007). Zakonomernosti dviženiâ psihologičeskogo poznaniâ i problema metoda nauki [Regularities of Development of Psychological Cognition and the Problem of the Method in Science]. Metodologiâ $i$ istoriâ psihologii, 1.

Klochko, V.E. (2008). Smyslovaâ teoriâ myšleniâ v transspektive stanovleniâ psihologičeskogo poznaniâ: èpistemologičeskij analiz [The Sense Theory of Thinking in the Transspective of Emergence of Psychological Cognition: Epistemological Analysis]. Vestnik Moskovskogo universiteta. Seriâ 14 "Psihologiâ," 2.

Klochko, V.E., \& Galazhinsky, E.V. (2009). Psihologiâ innovacionnogo povedeniâ [Psychology of Innovative Behaviour]. Tomsk.

Leontiev, A.N. (1975). Deâtel'nost', soznanie, ličnost' [Activity. Consciousness. Personality]. Moscow: Politizdat.

Leontiev, A.N. (1994). Filosofiâ psihologii: Iz naučnogo naslediâ [Philosophy of Psychology: from Scientific Heritage]. Moscow: MGU.

Leontiev, D.A. (2003). Psihologiâ smysla: priroda, stroenie i dinamika smyslovoj real'nosti [Psychology of Sense: Nature, Structure and Dynamics of Sense Reality]. Moscow: Smysl.

Lotman, Yu.M. (2000). Semiosfera [Semiosphere]. Saint Petersburg: Iskusstvo-SPB.

Malinetsky, G.G. Sinergetika. Korol' umer, da zdravstvuet korol'! [Synergy. The King is Dead, Long Live the King!] [http://www.keldysh.ru/departments/dpt_17/koru. html]

Nalimov, V.V. (1993). V poiskah inyh smyslov [Searching for New Senses]. Moscow: Progress.

Popper, K. (1984). An Evolutionary Epistemology. In J.W. Pollard (Ed.), Evolutionary Theory: Paths into the Future (pp. 239-255). Chichester \& New York: Wiley.

Toulmin, S. (1981). Mocart v psihologii [The Mozart of Psychology]. Voprosy filosofii, 10 .

Uznadze, D.N. (2000). Antologiâ gumannoj pedagogiki [Antology of Humane Pedagogy]. Moscow: Izdatel'skij Dom Šalvy Amonašvili.

Vygotsky, L.S. (1982). Istoričeskij smysl psihologičeskogo krizisa [Historical Meaning of the Psychological Crisis]. In Sobranie sočinenij v $6 t$. T. 1. [Collected Works in 6 vol. Vol. 1]. Moscow: Pedagogika. 
Vygotsky, L.S. (1983). K voprosu o dinamike detskogo haraktera [To the Question of Child's Character Dynamics]. In Sobranie sočinenij v 6 t. T. 5. [Collected Works in 6 vol. Vol. 5]. Moscow: Pedagogika.

Vygotsky, L.S. (1986). Konkretnaâ psihologiâ čeloveka [Concrete Psychology of a Person]. Vestnik Moskovskogo universiteta. Seriâ 14 "Psihologiâ," 1.

Zajonc, R.B. (1984). On the Primacy of Affect. American Psychologist, 39, 117-123.

Zavershneva, E.Yu. (2008). Zapisnye knižki, zametki, naučnye dnevniki L.S. Vygotskogo: rezul'taty issledovaniâ semejnogo arhiva [Notebooks, Notes, Scientific Diaries of L.S. Vygotsky: Family Archive Research Results]. Voprosy psihologii, 2. 